Johnson \& Wales University ScholarsArchive@JWU

Humanities Department Faculty Publications \&

Research

College of Arts \& Sciences

$1-1-2003$

\title{
Radio Regulation Revisited: Coase, the FCC, and the Public Interest
}

David A. Moss

Harvard Business School

Michael R. Fein Ph.D.

Johnson \& Wales University - Providence, mfein@jwu.edu

Follow this and additional works at: https://scholarsarchive.jwu.edu/humanities_fac

Part of the Cultural History Commons, European History Commons, Other History Commons, and the United States History Commons

\section{Repository Citation}

Moss, David A. and Fein, Michael R. Ph.D., "Radio Regulation Revisited: Coase, the FCC, and the Public Interest" (2003). Humanities Department Faculty Publications \& Research. 2.

https://scholarsarchive.jwu.edu/humanities_fac/2

This Article is brought to you for free and open access by the College of Arts \& Sciences at ScholarsArchive@JWU. It has been accepted for inclusion in Humanities Department Faculty Publications \& Research by an authorized administrator of ScholarsArchive@JWU. For more information, please contact jcastel@jwu.edu. 


\section{DAVID A. MOSS AND MICHAEL R. FEIN}

\section{Radio Regulation Revisited: Coase, the FCC, and the Public Interest}

It is now more than forty years since Ronald Coase's seminal article on the Federal Communications Commission first appeared in the pages of the Journal of Law and Economics. ${ }^{1}$ The article remains important for a number of reasons, not least of which is that it offered his first articulation of the Coase Theorem. ${ }^{2}$ Of even greater importance for our purposes, the article literally redefined the terms of debate over American broadcast regulation, in both historical and contemporary treatments of the subject.

Focusing particularly on the development of radio regulation, Coase rejected the prevailing notion that the establishment of the Federal Communications Commission (FCC) served the public interest. Rather, he concluded that its creation had been a mistake, the product of faulty economic reasoning. The complex regulatory apparatus developed under the Federal Radio Act of 1927 and recodified in the Federal Communications Act of 1934 was built on the flawed assumption that scarce resources-in this case the radio spectrum-had to be allocated by government fiat. A more efficient solution, Coase maintained, would have been to allocate the spectrum like any other scarce resource, on the basis of well-defined property rights and a free market guided by the price mechanism. Indeed, this is why he suggested that the spectrum ought to be cut up and sold at auction rather than regulated by the federal government. ${ }^{3}$

While Coase's economic reasoning and policy conclusions have since gained wide acceptance, the historical work on which the ar-

\footnotetext{
We would like to thank Alexander Dyck, Marjorie Feld, Walter Friedman, Mark Rose, Jim Wooten, Brian Zuckerman, and the four anonymous referees from this journal for their valuable comments on earlier drafts of this article. We would also like to thank Sarah Brennan and Mary Oey for research assistance.
} 
ticle was based has taken quite a beating. Thomas Hazlett, in particular, has demonstrated that federal lawmakers of the 1920s were in no way blind to the property-rights option, but rather knowingly rejected it in favor of far-reaching regulation. ${ }^{4}$ In Hazlett's view, radio regulation was the product not of ignorance or mistaken reasoning, but rather of an implicit deal between policymakers on the one hand and incumbent broadcasters on the other, both of whom had much to gain from a regulatory solution. "That the political marketplace pointedly vetoed a property rights solution that would bypass regulators and legislators while holding entry open into broadcasting," Hazlett asserted, "was not a reflection of technical incompetence but of self-interested rationality." ${ }^{5}$ Yet even after contradicting Coase's rendition of the historical record, Hazlett applauded Coase's central policy conclusion-that a well-conceived plan to auction the spectrum would better serve the public interest than did the existing regulatory regime. ${ }^{6}$

At the heart of Hazlett's critique was not only a rejection of what he called the "error theory" of broadcast regulation, but also a rejection of the public-interest theory of policymaking that lay behind it. ${ }^{7}$ In Coase's version of the story, policymakers seem to have meant well: they failed to adopt a property-rights solution-and thus failed to serve the public interest, according to Coase-only as a result of bad reasoning, not bad motives. In Hazlett's version, by contrast, lawmakers were fully aware of the property-rights option but rejected it on the basis of "self-interested rationality."

Like Hazlett and others who have studied the history of radio regulation in recent years, we find considerable evidence that proponents of the "error theory" (including Coase himself) mischaracterized the historical record. Unlike most other students of the subject, however, we do not believe the available evidence proves that lawmakers were guided mainly by self-interest, as opposed to their own sense of the public interest, in fashioning a regulatory regime for radio. According to our reading of the legislative record, American lawmakers presented a perfectly reasonable and logically consistent case for federal regulation of broadcasting. Their often-repeated concerns about limited spectrum, which so fascinated Coase, had less to do with their interest in finding an economically efficient allocation of scarce bandwidth than with their determination to prevent a potentially dangerous concentration of political power. Coase's mistake, we believe, was not in assuming that lawmakers were guided by a concern for the public interest, but rather that ef- 
ficiency considerations were (or ought to have been) paramount in assessing the public interest.

What the record reveals is that democratic principles came into conflict with-and ultimately eclipsed-economic ones in the legislative debate, a result that was contextually specific to broadcasting. Had radio been more like newspaper, where there was no obvious limit on the number of independent voices that could be heard, policymakers might well have anticipated Coase's advice in adopting a market approach to spectrum allocation. ${ }^{9}$ But, given the (apparent) reality of a limited radio spectrum and the extraordinary political influence that the right to broadcast seemed to convey, federal lawmakers turned fiercely against a market solution. It was not that they regarded regulation as the only way to prevent interference on the airwaves (as Coase maintained), but rather that they saw regulation as the best way to prevent the airwaves from being dominated by just a small number of voices.

These findings obviously raise questions about Coase's normative claim that spectrum auctions would better serve the public interest than regulation. As the early legislative record suggests, much depends on one's conception of the public interest. But these findings also pose a clear challenge to those who, in recent years, have reinterpreted the history of radio regulation from a rent-seeking perspective. Perhaps the officials who supported regulation fashioned arguments about concentrated political power merely as a means of covering up their true-and far more selfish-motivations. But perhaps not. The point here is that the legislative record offers little reason to doubt either their competence or their sincerity, and it thus offers little contradiction to the so-called public-interest theory of policy formation. While in no way denying that rent seeking may have played a role in the rise of radio regulation, we maintain that the public-interest theory of radio regulation has been too easily dismissed in the wake of Ronald Coase.

\section{Coase and the History of the FCC}

Ronald Coase's reading of the historical record led him to believe that the "main reason for government regulation of the radio industry was to prevent interference." ${ }^{10}$ First with ship-to-ship and shipto-shore communication, and later with radio broadcasting, the cacophony of voices transmitted over a limited radio spectrum threat- 
ened to undermine the utility of the entire medium. Convinced that regulation was the best (and perhaps the only) way to bring order to this otherwise chaotic technology, federal lawmakers passed the Radio Act of 1927, which created the Federal Radio Commission, the forerunner to the FCC.

Coase supported this account with numerous quotes from public officials. Perhaps most striking was an extended passage from a 1943 Supreme Court decision, in which Justice Felix Frankfurter (writing for the court) characterized the history and logic of radio regulation precisely as Coase had described it:

The plight into which radio fell prior to 1927 was attributable to certain basic facts about radio as a means of communication-its facilities are limited; they are not available to all who may wish to use them; the radio spectrum is simply not large enough to accommodate everybody. There is a fixed natural limitation upon the number of stations that can operate without interfering with one another. Regulation of radio was therefore as vital to its development as traffic control was to the development of the automobile. In enacting the Radio Act of 1927, the first comprehensive scheme of control over radio communication, Congress acted upon the knowledge that if the potentialities of radio were not to be wasted, regulation was essential. ${ }^{11}$

Resource scarcity and the potential for interference, in other words, are what necessitated an aggressive regulatory response.

Satisfied that this was indeed the logic by which radio regulation had been (and continued to be) justified, Coase proceeded to rip it apart. "Notwithstanding the general acceptance of these arguments and the eminence of the authorities who expound them," he wrote, "the views which have just been quoted are based on a misunderstanding of the nature of the problem." The notion that radio required special economic treatment merely because of a dearth of usable frequencies struck Coase as absurd. It was, after all, "a commonplace of economics that almost all resources used in the economic system ... are limited in amount and scarce." Since most scarce resources were allocated privately in the marketplace, rather than through government edict, why should radio be any different? "It is true," Coase conceded, "that some mechanism has to be employed to decide who, out of the many claimants, should be allowed to use 
the scarce resource. But the way this is usually done in the American economic system is to employ the price mechanism, and this allocates resources to users without the need for governmental regulation."12

Though radio interference may have seemed like a novel problem at the time, particularly given the newness of this "mysterious technology," Coase insisted that the same essential problem affected every scarce resource, including land. ${ }^{13}$ "The use of a piece of land simultaneously for growing wheat and as a parking lot," he noted, "would produce similar results. .. . [T] he way this situation is avoided is to create property rights (rights, that is, to exclusive use) in land. The creation of similar rights in the use of frequencies would enable the problem to be solved in the same way in the radio industry." ${ }^{14}$ Had the nation's lawmakers simply thought more clearly and soberly about the challenge at hand, they would have recognized that welldefined property rights and the price mechanism-not regulationwere all that was needed to allocate the radio spectrum in a socially optimal manner. As it was, federal radio regulation was nothing more than the unfortunate product of poor economic reasoning.

\section{Finding Error in the "Error Theory" of Radio Regulation}

Although the historical treatment of radio regulation evolved considerably in subsequent years, Coase's reading remained largely intact until 1990, when Thomas Hazlett published a devastating critique-once again in the Journal of Law and Economics. ${ }^{15}$ Characterizing the prevailing interpretation as the "error theory' of federal licensing" (since it held that radio regulation was mostly attributable to muddled thinking), Hazlett provocatively argued that there was really no error at all. ${ }^{16}$ Federal policymakers had known exactly what they were doing in 1927. In fact, in Hazlett's view, the Federal Radio Act represented an explicit rejection of a recent judicial attempt to craft precisely the sort of property-rights regime that Coase would later recommend.

The key case upon which Hazlett relied was Tribune Co. v. Oak Leaves Broadcasting Station, a 1926 decision that addressed the interference problem by creating a homesteading right for existing stations. The defendant in the case, described as a "wave jumper," was ordered not to broadcast within 50 kilocycles of the plaintiff, a more established station with a longer record on the contested frequency. 
"It was on this homesteading principle," Hazlett explained, "that the judge found a common-law remedy to the potential 'tragedy of the commons.' Relying on established law ... the opinion granted a priority-in-use property-rights rule the force of law in radio broadcasting. Private rights in the ether under common law were immediately recognized as a solution to the interference problem." ${ }^{17}$

As Hazlett tells the story, the Oak Leaves decision was received like a lightening bolt at the U.S. Commerce Department, where Secretary Herbert Hoover "had been advocating broadcasting legislation since the early 1920s." 18 What Hoover wanted was federal authority to grant radio franchises based on a "public interest" standard. A believer not only in big business but also in corporate service to the commonweal, Hoover insisted that every prospective radio licensee should be "compelled to prove that there is something more than naked commercial selfishness in his purpose." ${ }^{19}$ His vision, however, was profoundly threatened by the Oak Leaves decision, which promised to create a true property-rights regime tied neither to Hoover's regulatory authority nor to his expansive notion of the public interest. ${ }^{20}$

Until 1926, Hoover's Commerce Department had been in the business of assigning broadcast licenses. Though the authorizing legislation (the federal Radio Act of 1912) was originally created to cover point-to-point communication, federal regulators took it upon themselves to extend its coverage to broadcasting as well, once radio broadcasting began to take shape around 1920. Yet in 1923 and again in 1926, federal courts ruled against the Commerce Department's licensing policy, denying that Congress had granted the department any real discretion over the allocation of radio licenses. The 1926 decision, announced several months before Oak Leaves, proved particularly debilitating, since it rejected the department's authority even to assign wavelengths and times of operation. ${ }^{21}$ Rather than try to appeal the case or encourage voluntary cooperation among broadcasters, Secretary Hoover seemed to throw in the towel, apparently content to allow chaos to consume the airwaves. "By any nonstrategic standard," Hazlett observed, "the regulatory reaction to market confusion was inexplicable." 22 One possible answer is that Hoover's actions were in fact strategic. "Chaos," explains Hazlett, "was strategically introduced into the political process" to "pressure Congress for action." 23

By most accounts, the strategy-if that is what it was-appears to have worked. Congress moved quickly in late 1926 and early 1927 
to craft a comprehensive regulatory solution. Signed into law on 23 February 1927, the Radio Act created a new Federal Radio Commission and authorized it to grant broadcast licenses whenever it determined "that public interest, convenience, or necessity would be served." ${ }^{4}$ Far from being fashioned out of ignorance, Hazlett maintains, the Radio Act represented a conscious rejection of the property-rights approach that was just then emerging in the courts. ${ }^{25}$

In place of the flawed "error theory" of radio regulation, Hazlett has offered his own "franchise-rents" theory, which characterizes American radio law as the product of "self-interested rationality," in which the major players-particularly federal policymakers and the leading radio broadcasters - each achieved advantages that would have been unattainable in an unregulated market. ${ }^{26}$ "The bargain instituted was a classic regulatory quid pro quo wherein incumbent radio broadcasters agreed to be subject to 'public interest' licensing requirements in exchange for barriers to new entry." Leading broadcasters were assured of increased rents (since the new regulatory regime would deny upstart competitors the right to "homestead unoccupied bands"), while Congress "gained some measure of authority over this newly evolving medium of expression."27

There can be no doubt that Hazlett's work has dramatically advanced our understanding of the origins of broadcast regulation in the United States, overturning the "error theory" and underscoring the critical role of strategic and rent-seeking behavior on the part of broadcasters and lawmakers alike. Yet several important questions still remain unanswered. Why did Coase (and others who followed him) get the history so wrong? If, as Hazlett contends, "interference was not the problem," what led Coase to believe that it was in fact a problem of central importance? ${ }^{28}$ And if the economic viability of the property-rights option was indeed plainly visible at the time, why were American lawmakers (well known for their anti-statist sentiments) so intent, as Senator C. C. Dill put it, on "prevent[ing] private ownership of wave lengths" and asserting the "full sovereignty over radio by Congress"? ${ }^{29}$ Hazlett maintains that these lawmakers sought to place themselves at the "nexus of decision making in a brisk competitive rivalry for zero-priced frequency rights" and thus to provide themselves with "a very well understood discretion over the life and death of lucrative and influential broadcasters." ${ }^{30}$ But then why did they not choose to regulate every industry to the same extent (or at least to the extent legally-or constitutionally-permissible)? Perhaps radio was special. But if so, why would Hazlett, 
after correcting Coase's history, ultimately agree with Coase's normative conclusion that broadcast frequencies ought to be allocated in the private marketplace, on the basis of property rights and prices, like any other resource? ${ }^{31}$ Was radio special, or not?

The answer, in short, is that radio was special. Certainly other nations, which placed strong state controls over the medium, considered it to be so. ${ }^{32}$ And American lawmakers, though easing private access to the spectrum and promulgating a tamer version of public oversight, felt no differently about its exceptional nature. Radio was regarded as special, however, not because of some distinctive economic characteristics, but rather because of distinctive political characteristics associated with the power to broadcast and to shape public opinion. Surely some policymakers (though by no means all) understood that radio interference could be solved in the private marketplace once property rights in the spectrum were assigned. But they feared that such a strictly economic solution to the problem of interference could itself create a political problem of vastly greater consequence, permanently concentrating control over mass communication in too few hands. What drove them toward a regulatory rather than a common-law solution, then, was the combination of spectrum scarcity on the one hand and radio's enormous political significance on the other. Had either of these characteristics been absent, a property-rights approach would have sufficed. Together, they seemed to pose such a grave threat to the democratic process that lawmakers felt they had no choice but to establish direct regulatory control over the industry.

\section{Fear of Concentrated Control over the "Most Potent Political Instrument of the Future"}

Many scholars, including both Coase and Hazlett, have noted that federal policymakers often worried about broadcasters obtaining too much influence over public opinion. But it seems that no one has yet demonstrated just how pivotal this concern was in the shaping of federal radio legislation. As the historical record makes clear, a pervasive fear of political monopoly - that is, of concentrated control over this new and unparalleled means of political expressionprofoundly influenced the legislative process at almost every step of the way. 
Such a fear already loomed large in 1924, when Secretary Hoover urged Congress to assert more explicit and expansive public control over the radio spectrum. "It is inconceivable," he declared during a congressional hearing,

that the American people will allow this new-born system of communication to fall exclusively into the power of any individual group or combination. Great as the development of radio distribution has been, we are probably only at the threshold of the development of one of the most important of human discoveries bearing on education, amusement, culture, and business communication. It can not be thought that any single person or group shall ever have the right to determine what communication may be made to the American people....

[T] he fundamental thought of any radio legislation should be to retain possession of the ether in the public and to provide rules for orderly conduct of this great system of public communication by temporary permits to use the ether. It should be kept open to free and full individual development, and we should assure that there can be no monopoly over the distribution of material. ${ }^{33}$

Not surprisingly, a representative of the Radio Broadcasters' Society of America, a group of independent stations, wholeheartedly agreed:

If [radio broadcasting] is put into the hands of a trust, into the hands of a monopoly-if a monopoly is not stopped now, and they get control in this country-it might well be that some official of the monopoly company, sitting in the quiet of his executive office, surrounded and protected and away from the public, where he can not be seen, will issue the fiat that only one kind of religion shall be talked over the radio; that only one kind of politics shall be talked over the radio; that only one candidate can give messages to the people; that only one kind of soap can be advertised. ${ }^{34}$

When Raymond Asserson, speaking at the same set of hearings on behalf of the New York City Broadcasting Supervisor, expressed concern about superpower stations having "great power of influence over the public," Representative George W. Edmonds of Pennsylva- 
nia replied, "The point you are making is this, that if it should get into the control of two or three hands, they could shut out certain lines of conversation, talk, or speeches over the radio, and allow others in, just to suit their purposes." ${ }^{35}$ Asserson agreed, claiming that there is a "danger there, in advocating that policy [of allowing high-power broadcast stations], of really advocating monopoly of the air." 36 Although David Sarnoff of RCA insisted that superpower stations would not interfere with other wavelengths, Asserson maintained that the RCA-affiliated superstation in Bound Brook, New Jersey, was already blocking out independent broadcasters. ${ }^{37}$

A related problem that concerned many lawmakers was the emerging secondary market for spectrum rights. By the mid-1920s, it had become commonplace for those seeking access to the spectrum to purchase existing stations and petition federal regulators for license transfers. Cognizant of the substantial investments involved, the Commerce Department typically reassigned licenses with little debate. As Hazlett explained it, Secretary Hoover "relied on market transactions to minimize broadcasting disruptions, à la the Coase Theorem." 38 But many legislators worried that if a license effectively ran with the radio apparatus, then there would be nothing to prevent the concentration of broadcasting rights in a single person or firm. ${ }^{39}$

Believing that it was essential to preempt the creation of any true property rights in the spectrum, Senator Robert B. Howell of Nebraska proposed a bill reasserting the public's right to the ether in 1926. Solicitor Stephen B. Davis of the Commerce Department explained that the bill "would compel the disclaiming of any such claim" of vested rights in the ether. When Chairman C. C. Dill of the Senate Interstate Commerce Committee asked Senator Howell if he knew of any such claims, Howell replied that "such claims are contemplated," and that he introduced the bill "to force to the surface now, and not 25 years from now, any claim of vested right." This would "enable Congress to deal with them now in the infancy of this art." 40

Lawmakers apparently feared that tradable rights in the spectrum could easily lead to an unacceptable concentration of power in broadcasting. Afraid of precisely such an outcome, Senator James B. Couzens of Michigan quizzed Davis about the Commerce Department's routine approval of license transfers in the overcrowded Chicago market. "[I]f that policy was carried on," Couzens asked, "it could monopolize the whole district by buying up stations, could it 
not?" Davis noted that there was no evidence as yet of any such monopoly forming, but Couzens persisted.

Couzens: If priority is ignored in that case then the apparatus controls the situation, and anyone that buys the apparatus can control the situation.

Davis: We have felt this way about it, Senator, that the license ran to the station rather than to the individual. In other words, we have never felt it wise to adopt a policy under which we would say to an individual, "Yes; go in and build this station at whatever cost there may be. If you die it is worth nothing. If you change your mind and want to quit broadcasting it is worth nothing. If you get into business trouble it is worth nothing to your creditors. It has only got a refuse value." We take the position that inasmuch as these licenses are only 90-day licenses anyway, that the license ran to the apparatus; a man can transfer his apparatus, and if there is no good reason to the contrary we will recognize that sale and license the new owner of the apparatus.

Couzens: Well, it seems to me, then, it is up to Congress to provide some means whereby no single interest can control the broadcasting of the district. ${ }^{41}$

Later on in the hearings, when the Chicago market again came to the fore, Solicitor Davis reassured the committee that there was "no absolute right of transfer." 42 With more than forty stations in the Chicago area, there was no chance of one company monopolizing regional broadcasting, so long as no vested property rights were established in the ether. ${ }^{43}$ But Couzens maintained that "if and of necessity these stations must be restricted in number, it is perfectly obvious to me that it will only be a short time before it becomes a monopoly, and there is nothing in the law, and there is nothing in your jurisdiction, which would prevent that as long as you have in mind, and somewhat properly so, that the investment itself is entitled to some protection." 44 When Davis explained that the elimination of a right to transfer would impose enormous costs on incumbents, severely compromising the value of their investments, Couzens declared that he did not object to a station owner "selling what rights he has so long as he does not tack on anything for his license from the Government. In other words, I do not believe that 
we are justified in creating a franchise value for the privilege to broadcast." 45

As Senator Couzens made clear, the creation of a "franchise value" in radio frequencies ran contrary to the spirit of the proposed legislation. Congress sought to maintain the spectrum as a publicly owned resource because of its special nature. It was not just that radio frequencies were scarce, but that radio was, in Representative Ewin L. Davis's words, "the most potent political instrument of the future." ${ }^{46}$ If power over this instrument were ever concentrated in the wrong hands, it could threaten the very foundations of the republic.

Though a great many lawmakers adhered to this logic, Representative Luther A. Johnson of Texas probably articulated it as clearly as anyone ever did during a congressional floor debate in 1926. "There is no agency so fraught with possibilities for service of good or evil to the American people as the radio," he explained.

As a means of entertainment, education, information, and communication it has limitless possibilities. The power of the press will not be comparable to that of broadcasting stations when the industry is fully developed. If the development continues as rapidly in the future as in the past, it will only be a few years before these broadcasting stations, if operated by chain stations, will simultaneously reach an audience of over half of our entire citizenship, and bring messages to the fireside of nearly every home in America. They can mold and crystallize sentiment as no agency in the past has been able to do. If the strong arm of the law does not prevent monopoly ownership and make discrimination by such stations illegal, American thought and American politics will be largely at the mercy of those who operate these stations. For publicity is the most powerful weapon that can be wielded in a Republic, and when such a weapon is placed in the hands of one, or a single selfish group is permitted to either tacitly or otherwise acquire ownership and dominate these broadcasting stations throughout the country, then woe be to those who dare to differ with them. It will be impossible to compete with them in reaching the ears of the American public.

Subsidy of radio broadcasting would be far more effective and dangerous than subsidy of the press. For if every newspaper in the United States could be purchased by some trust or 
combination, independent and competing newspapers could be established. But if the broadcasting stations, which are necessarily limited in number, can be acquired, or even a majority of the high-powered stations owned and controlled by a trust, then the public will be helpless to establish others, unless the Government protects them in this right. Freedom of the air will be impossible if the Government either licenses or permits monopoly ownership of radio sending stations. ${ }^{47}$

Johnson's analogy to the newspaper industry went to the very heart of the issue. In his 1959 article, Coase claimed that there was no meaningful distinction between the publication of newspapers and radio broadcasting. ${ }^{48}$ But the fact that entry could conceivably be limited in one but not the other, Johnson argued, made all the difference in an arena so critical to the democratic process.

As it turned out, the House and Senate each passed its own version of radio legislation at the end of 1926, prodded by recent court decisions and perhaps by Hoover's supposed chaos strategy as well. According to Senator Dill, while the two bills "differed widely as to who should have the authority to regulate radio [the Secretary of Commerce or the Federal Radio Commission], they both contained provisions to prevent the users of radio apparatus from maintaining or even asserting any claim to the ownership of any vested rights in wave lengths." With no time available to resolve their differences before the end of the legislative session, each house rushed to pass a joint resolution in 1926, negating any private claims of spectrum ownership in the meantime. ${ }^{49}$

The new Congress that convened in 1927 moved quickly to pass a reconciled piece of legislation. An amalgam of the House and Senate versions, the resulting Radio Act included two strong antimonopoly provisions. One prohibited the unlawful monopolization of radio communication, while another outlawed the ownership of radio and wire systems in combination. ${ }^{50}$ With the behemoth AT\&T clearly in mind, Congress sought to remove any possibility that radio broadcasting would fall into the hands of this, the nation's greatest communications monopoly. ${ }^{51}$ But it was the hallmark regulatory standard of "public interest, convenience, or necessity" that provided the new commission with its most powerful weapon for preempting concentrated control over radio broadcasting - and one that was conceptually distinct from the prevailing standard in antitrust law. 
Whereas the objective in antitrust was to bar "restraint of trade," the goal of the Radio Act was to prevent, among other things, restraint of diverse expression over the airwaves. To be sure, some lawmakers who were frustrated with the Justice Department's handling of antitrust matters (particularly Senator William Borah of Idaho, Senator Key Pittman of Nevada, and Representative Ewin Davis of Tennessee) hoped to create a new and far more aggressive antitrust vehicle under the guise of radio regulation. But this covert objective was more the exception than the rule. In its final form, the Radio Act split the power to control monopoly in the radio industry between the radio commission and the Justice department. ${ }^{52}$

Such dual regulation struck Coase as unnecessary. ${ }^{53}$ Yet what seemed redundant to Coase was in fact designed to provide critical flexibility in combating concentrated control over a resource that Carl J. Friedrich and Evelyn Sternberg tellingly characterized as a "molder of public opinion and an instrument of political power." 54 Under the Radio Act, if the Justice Department found evidence of monopolistic trade, the commission was authorized to revoke the offender's broadcast license. But that was only the tip of the iceberg. The statute's public-interest standard, in particular, allowed the commission to act in advance of specific antitrust violations and to address a much broader class of problematic behavior. ${ }^{55}$ As early as 1941, an FCC report on chain broadcasting made clear that while the commission "should administer its regulatory powers with respect to broadcasting in light of the purposes which the Sherman Act was designed to achieve," its power extended beyond that act's narrowly conceived mission. ${ }^{56}$ "We do not predicate our jurisdiction to issue the regulations on the ground that the network practices violate the antitrust laws. We are issuing these regulations because we have found that the network practices prevent the maximum utilization of radio facilities in the public interest." ${ }^{57}$

Those who crafted the nation's radio legislation never fully explained why they believed existing antitrust law would be insufficient to achieve their objectives. Presumably, the notion that antitrust law, an economic instrument, would not be optimal for addressing concentrations of political power on the airwaves was so obvious that it was simply taken for granted.

Certainly, the notion that radio broadcasting carried special political significance was plain enough. In addition to establishing the public-interest standard, federal lawmakers also imposed a strict prohibition on broadcast licenses being granted or transferred to for- 
eigners, or even to "any company, corporation, or association of which any officer or director is an alien, or of which more than one-fifth of the capital stock may be voted by aliens or their representatives or by a foreign government or representative thereof, or by any company, corporation, or association organized under the laws of a foreign country." 58 As Representative Wallace H. White of Maine explained in 1924, "This means of communication within our borders should be in the hands and control of those loyal to this country." 59

The resulting prohibition on foreign control over broadcast licenses hardly fits neatly into a rent-seeking model of policy formation, since incumbent broadcasters must have recognized at the time that a legal constraint on the demand for their assets was unlikely to redound to their economic benefit. Nor can the prohibition be explained by appealing to a simple economic-efficiency version of the public-interest model. To be sure, a rule limiting foreign control over broadcasting would have been unnecessary had the radio spectrum merely constituted an economic resource like any other, as Coase later insisted. The truth is that this unusual prohibition was written into the law precisely because the spectrum was regarded as no ordinary resource. Indeed, Coase's contention that "there is nothing about the broadcasting industry which would lead us to believe that the allocation of frequencies constitutes an exceptional case" strangely overlooks the medium's enormous political consequence, which was almost universally recognized at the time. ${ }^{60}$

\section{Coase, Radio Regulation, and the Supreme Court}

Not surprisingly, the same essential oversight also biased Coase's assessment of the Supreme Court and its take on radio regulation. As will be recalled, Coase dismissed Justice Frankfurter's argument for federal regulation, articulated in FCC $v$. National Broadcasting Co. (1943), as based on nothing more than simple resource scarcity: "Mr. Justice Frankfurter seems to believe that federal regulation is needed because radio frequencies are limited in number and people want to use more of them than are available. But it is a commonplace of economics that almost all resources used in the economic system (and not simply radio and television frequencies) are limited in amount and scarce." 61 
Yet Frankfurter's opinion was considerably more sophisticated than Coase suggested. The justice clearly explained with regard to the Federal Communications Act of 1934 that its provisions "preclude the notion that the Commission is empowered to deal only with technical and engineering impediments to the "larger and more effective use of radio in the public interest." ${ }_{62}$ Indeed, as Frankfurter acknowledged, the FCC was charged with bringing about a socially optimal use of the medium that was not likely to be achieved in an unregulated market. Speculating about what might happen in the absence of public control over spectrum allocation, he wrote:

Suppose, for example, that a community can, because of physical limitations, be assigned only two stations. That community might be deprived of effective service in any one of several ways. More powerful stations in nearby cities might blanket out the signals of the local stations so that they could not be heard at all. The stations might interfere with each other so that neither could be clearly heard. One station might dominate the other with the power of its signal. But the community could be deprived of good radio service in ways less crude. One man, financially and technically qualified, might apply for and obtain the licenses of both stations and present a single service over the two stations, thus wasting a frequency otherwise available to the area. ${ }^{63}$

Citing liberally from an opinion he had written three years earlier, Frankfurter explained that the scarcity of resources was not the single, nor even the most important, motivating factor behind radio legislation. Instead, concern over the concentration of private power in radio broadcasting drove the legislature to act. "Congress," he had observed in 1940, "moved under the spur of a widespread fear that in the absence of governmental control the public interest might be subordinated to monopolistic domination in the broadcasting field." ${ }^{4}$ The Communications Act, which emerged from this regulatory impulse, was "not designed primarily as a new code for the adjustment of conflicting private rights through adjudication. Rather it expresses a desire on the part of Congress to maintain, through appropriate administrative control, a grip on the dynamic aspects of radio transmission." ${ }^{65}$

If Coase underestimated Frankfurter's understanding of the interference problem and the logic of regulation, he himself relied on 
a rather particular reading of the First Amendment. "The situation in the American broadcasting industry," Coase wrote,

is not essentially different in character from that which would be found if a commission appointed by the federal government had the task of selecting those who were to be allowed to publish newspapers and periodicals in each city, town, and village of the United States. A proposal to do this would, of course, be rejected out of hand as inconsistent with the doctrine of freedom of the press. ${ }^{66}$

Yet when applicants for broadcast licenses appealed to the Supreme Court, complaining that a denial of a license constituted an abridgment of free speech, the court was unsympathetic. Not content with the absolutist view of the First Amendment that the broadcasters put forth, the majority concluded in 1943 that "denial of a station license . . . is not a denial of free speech."67

The logic behind this distinction became clear some years later in a landmark 1969 decision, Red Lion Broadcasting Co. v. FCC. Here the court explained that far from restricting free speech, licensing restrictions actually helped to preserve it. The limited nature of the spectrum prevented all applicants from gaining access to broadcast stations. But in the absence of public regulation, those who gained access could easily use their power to preclude others from being heard. Thus the court determined that "the right of free speech of a broadcaster ... . does not embrace a right to snuff out the free speech of others." 68 It also clarified the essential justification for the FCC's equal-time rule, which the appellants in the case had vigorously protested as a violation of their First Amendment rights. "Where there are substantially more individuals who want to broadcast than there are frequencies to allocate," the court announced,

it is idle to posit an unbridgeable First Amendment right to broadcast comparable to the right of every individual to speak, write, or publish. If 100 persons want broadcast licenses but there are only 10 frequencies to allocate, all of them may have the same "right" to a license; but if there is to be any effective communication by radio, only a few can be licensed and the rest must be barred from the airwaves. It would be strange if the First Amendment, aimed at protecting and furthering communications, prevented the Government from making 
radio communication possible by requiring licenses to broadcast and by limiting the number of licenses so as not to overcrowd the spectrum.

This has been the consistent view of the Court. ...

... No one has a First Amendment right to a license or to monopolize a radio frequency.... It is the purpose of the First Amendment to preserve an uninhibited marketplace of ideas in which truth will ultimately prevail, rather than to countenance monopolization of that market, whether it be by the Government itself or a private licensee. ${ }^{69}$

Red Lion made it clear that the First Amendment provided no immunity from the FCC's licensing power. Concern over the monopolization of the airwaves remained paramount in the justices' minds, a trend that was apparent as early as the 1940 Pottsville decision. As the court's successive rulings made clear, the needs of private broadcasting companies were subordinate to the public interest as determined by the FCC. Federal regulation of the airwaves was not, as Coase had insisted, equivalent to "selecting those who were to be allowed to publish newspapers and periodicals in each city, town, and village of the United States."

Within this context, moreover, Hazlett's economistic notion that the problem of scarcity would inherently be solved if frequencies were priced in the private market seems oddly out of place. The Court's sense of scarcity-defined presumably as insufficient opportunity for diverse and independent political expression on the airwaves-would hardly be solved by Coase and Hazlett's "price-rationing mechanism," even if "excess demand for licenses" were indeed "eliminated" in the process. ${ }^{70}$ Surely, a market for another politically consequential resource, votes, would eliminate scarcity in strictly economic terms, by allowing those most interested in electoral outcomes to obtain the votes of the relatively apathetic. But it would do so only by generating unacceptable scarcity in a political sense, by denying sufficient opportunity for individual input into the democratic process.

Indeed, this was the implicit logic that led policymakers to react so strongly beginning in the 1920s against the notion of permanent property rights in the spectrum and the rationing of broadcast frequencies through the price mechanism. A proposal to allocate votes in the marketplace would obviously have been greeted with even greater alarm, but — and this is the important point—it would 
have been opposed for many of the same reasons. There are certain places, apparently, where economic and political imperatives simply do not mix.

\section{Radio Regulation and the Public Interest}

By viewing the radio spectrum as nothing more than a standard economic resource, Coase missed what was for many lawmakers its defining characteristic. The unprecedented power to communicate and to shape public opinion that radio allowed had profound implications for American politics and, indeed, for the democratic process itself.

In a very real sense, radio broadcasting threatened one of the nation's most trusted bulwarks against tyranny. As James Madison had observed in Federalist 10, it was the cacophony of voices, spread out over vast distances, that served as the greatest guardian of the democratic process in America. Not only would a multitude of disparate factions render it virtually impossible for any stable-and potentially tyrannous-majority to form, but individual factions would find it hard to reach very far beyond their own locales in a nation as large as the United States. "The influence of factious leaders," Madison wrote, "may kindle a flame within their particular States but will be unable to spread a general conflagration through the other States." Because "communication is always checked by distrust, in proportion to the number whose concurrence is necessary," a demagogue's power would necessarily dwindle as it was projected further from its base. ${ }^{71}$ Madison's vision of a healthy democratic republic relied on a vigorous and disruptive competition among political interests-or, to put it another way, on intense and continuing interference in the political realm.

Radio broadcasting posed little threat to Madison's vision so long as it was filled with a cacophony of competing voices, crammed together on a raft of overlapping frequencies. But once the interference problem was solved through a rational method of spectrum allocation, broadcasting immediately threatened to provide some factions with unparalleled access to the public, based on a technology that collapsed space in the transmission of the human voice. ${ }^{72}$ Broadly speaking, this is why policymakers so feared the potential for concentrated control over broadcasting, why so many of them took for granted that spectrum allocation could never be left en- 
tirely to the private market, and why the Supreme Court so steadfastly guarded the authority of federal regulators in the years after the FCC was created.

Perhaps because the case for regulation was rarely stated with the kind of logical precision that economists demand of themselves, Coase misinterpreted the impassioned support for radio regulation that he found in the historical record merely as an expression of mass anxiety about a mysterious new technology. Convinced that the radio spectrum was indeed no different than any other economic resource, Coase refused to believe that the lawmakers' near universal support for a regulatory solution could be guided by anything but a "misunderstanding of the nature of the problem." It was a bit like Herbert Spencer, who claimed in the late nineteenth century that despite all the stories to the contrary, scientists should understand that it was physically impossible to throw a curve ball. Spencer's physics proved faulty because in thinking "scientifically" about the trajectory of a sphere moving through space, he assumed away two critical facts about the problem at hand: that there were stitches on baseballs and friction in the air. ${ }^{73}$ We believe that Coase committed a similar error in his work on the FCC by ignoring the crucial political significance of radio broadcasting.

Of course, all of this is not to say that pervasive fear about the potential for political monopolization of the airwaves was the only factor that led contemporary lawmakers to adopt the regulatory approach that they did. Hazlett's powerful insights about the benefits that major players derived from the arrangement remain as relevant as ever. ${ }^{74}$ Nor are we suggesting that the FCC has fully achieved the legislative objective of assuring diversity of expression on the airwaves that Congress set for it in the 1920s and 1930s.

Indeed, there is little doubt that federal radio policy favored commercial broadcasters over ideologically and religiously charged stations from the beginning. The regulators' chief goal-avoiding the monopolization of a scarce and politically significant resourcedid not extend to protecting single-issue stations. Instead, the goal was to promote stations that offered broadly oriented programming.

Although network radio derived great benefit from this regulatory approach (as Hazlett correctly maintains), it is simply too great a leap to interpret this outcome as strong evidence that congressional lawmakers and commercial broadcasters had colluded from the outset. As the relevant historiography makes clear, the regulators' preference for network broadcasters is consistent with an anti- 
labor thesis, a procorporate thesis, a rent-seeking thesis, and an antimonopoly thesis. It is also consistent with the simple proposition that regulators viewed these commercial broadcasters as especially unlikely to tyrannize the airwaves. ${ }^{75}$ The three bland networks that the FCC long tolerated - and even fostered-may not have created the sort of vibrant diversity that Congress originally intended; but neither did they exercise tyrannous control over political speech.

Our point is simply this: that the bulk of the evidence strongly suggests that the fear of concentrated control over mass communication mattered a great deal in the making of American radio regulation. The record also suggests that this concern about concentrated political power provided lawmakers with a perfectly reasonable basis upon which to conclude that a property-rights solution would not have been socially optimal. This was because their conception of the public interest-of what actions would be socially optimal-had at least as much to do with democratic principles as with notions of economic efficiency. Even if it arose as a result of purely voluntary market transactions, concentrated control over radio broadcasting could still represent a major threat to the republic. Coase's misreading of the historical record should thus serve as a warning to students of law and economics about the perils of assuming away critical real-life factors that do not fit neatly into our models, like those nettlesome stitches on a baseball.

This story, we believe, should also serve as a reminder that the public-interest theory of policymaking, long dismissed as naive, actually requires further evaluation. ${ }^{76}$ The fact that lawmakers advanced coherent arguments in support of federal radio regulation during the 1920s and 1930s is obviously not sufficient to confirm the public-interest theory. But it does provide a good reason to give the theory another look. If the lawmakers' often-repeated claim about the perils of concentrated control over the airwaves really were nothing more than a cover for selfish rent-seeking, then one would have to admit they put on a phenomenal show. We may never be certain about the true motivations of these lawmakers. What should be clear now, however, is that a public-interest reading of federal radio legislation finds little contradiction in the legislative record itself.

In fact, even today, ongoing developments in the arena of radio regulation seem only to bolster the public-interest perspective. As is well known, there has been a major push in recent years to deregulate the airwaves. Proponents of deregulation have sought, in particular, to create more genuine markets for spectrum rights (based 
initially on government auctions) and to reduce restrictions on media ownership (such as the rule blocking any individual company from owning more than a certain number of television and radio stations in a particular locale). This debate is of interest here for at least three reasons.

To begin with, there can be little doubt that Coase's ideas about the optimality of a market-based approach to spectrum allocation have ended up playing a central role in redefining the "public interest" and, in turn, in driving deregulation of the industry on publicinterest grounds. Speaking in support of spectrum auctions to a House subcommittee in 1997, FCC Chairman Reed Hundt emphasized both his pursuit of the public interest and his debt to Ronald Coase:

Congress and the FCC need to affirm a new paradigm of spectrum policy that relies on market techniques for commercial uses of spectrum. I believe that such a policy is the best way to ensure that spectrum is used to benefit the public. Marketbased spectrum policy is not based on new radical economic theories, but rather on sound principles that have been tried and true for 50 years. Nobel Laureate Ronald Coase wrote an article advocating market-based approaches for the FCC more than 35 years ago. ${ }^{77}$

In 2001, thirty-seven economists-among them Ronald Coase himself, two former members of the President's Council of Economic Advisors, ten former justice department officials, and six former FCC officials, including Thomas Hazlett-wrote a brief to the FCC urging "the Commission to advance the 'public interest' by eliminating barriers to the productive use of radio spectrum" (particularly with respect to wireless communications technologies). Noting that "none of us has been retained by any client concerning this submission" and that many economists had "written articles showing the benefits" of their proposed approach, they insisted that "market-oriented rules opening the radio spectrum" would capture "its full potential for society." 78 The current chairman of the FCC, Michael Powell, appears to have been duly convinced, suggesting in a recent interview that "the famous Ronald Coase treatise that won the Nobel Prize was about this-that [the traditional command-and-control] spectrum policy is lunacy. The market could work this out." 79

The relevant point for this article is that although notions of how best to serve the public interest have changed as a result of 
Coase's powerful economic arguments, there is no question that ideas about the public interest, however defined, are still of great import in shaping the policy debate. Indeed, there is a certain irony in the fact that many of the same economists who, in their scholarship, are quick to attribute legislative and regulatory outcomes to self-interested, rent-seeking behavior have nonetheless lobbied hard in recent years for deregulation of the spectrum-and, on top of that, that they have done so explicitly on public-interest grounds and have proved remarkably influential!

A second intriguing point to emerge from the current debate over deregulation of the airwaves is that the traditional argument about preventing concentrated control over a politically sensitive resource still resonates in the halls of Congress, though certainly not as loudly as it once did. Responding to continued calls for deregulation in 2001, for example, Senators Ernest Hollings and Byron Dorgan wrote in the Washington Post, "For decades, our communications policy has imposed sensible restrictions on media ownership to promote and preserve multiple, independent voices. ... [I]f media consolidation is allowed to continue unfettered ... local control, local coverage and a robust marketplace of ideas will suffer." Significantly, Hollings and Dorgan explicitly distinguished their goal of promoting "diversity and localism" on the airwaves from "narrow antitrust notions of competition," just as Congress had done in 1927.80

Even Hollings and Dorgan acknowledged, however, that this traditional argument in support of radio regulation was facing mounting criticism on the grounds that "current ownership restrictions are outmoded because of the proliferation of new media outlets." Which brings us to the third, and perhaps most fascinating, point about the current debate. According to a growing number of critics, the rise of the Internet, cable and satellite television, and the like have rendered the FCC obsolete, since there is no longer any meaningful limit on the number of independent voices that can be heard. ${ }^{81}$ Proponents of the traditional regulatory regime, including Hollings and Dorgan, counter this argument by noting that "most people still get their information from local newspapers, radio and television stations," rather than from the Internet. ${ }^{82}$

What we find most striking, however, is that this newest argument about the obsolescence of radio regulation is in fact perfectly consistent with the logic that was used to justify radio regulation in the first place. As we have shown, the early advocates of the FRC 
and the FCC rested their case on a combination of spectrum scarcity on the one hand and broadcasting's special political significance on the other. There was no need to regulate newspapers in the same way, they believed, because newspapers were characterized by only one of these attributes (political significance), but not both. If it is indeed correct to think about the Internet and other new communications technologies as effectively eliminating spectrum scarcity in broadcasting, as some now argue, then the traditional case for regulation-even if once correct-might now be defunct.

Curiously, all of these goings-on remind us of the old adage that the more things change, the more they stay the same. With respect to spectrum allocation, old conceptions of the public interest are now under attack, by Coasians on the one hand and new communications technologies on the other. Yet much of the debate still revolves around the special political significance of broadcasting. And despite the fact that there are many powerful and influential interests involved, it still appears that the current debate (like the historical one) can be understood fundamentally as a contest of ideas about how best to serve the public interest. How that debate is likely to turn out is a question that lies well beyond the scope of this article. But the very nature of the debate-and the fact that social scientists like Coase and Hazlett are themselves deeply involved in it (as experts, not rent-seekers)—should help to reinforce our historical argument that the public-interest perspective remains highly relevant, even if intensely unfashionable, in the realm of policy studies.

Harvard University Brandeis University

\section{Notes}

1. Ronald H. Coase, "The Federal Communications Commission," Journal of Law $\mathcal{E}$ Economics 2 (1959): 1-40.

2. Ibid., 26-27.

3. Ibid., esp. 12-40.

4. Thomas W. Hazlett, "The Rationality of U.S. Regulation of the Broadcast Spectrum," Journal of Law Ë Economics 33 (1990): 137-38 nn. 12-14.

5. Ibid., 175.

6. Thomas W. Hazlett, "Assigning Property Rights to Radio Spectrum Users: Why Did FCC License Auctions Take 67 Years?" Journal of Law EF Economics 41 (1998): 529. See also Hazlett, "Rationality of U.S. Regulation," 174.

7. Hazlett, "Rationality of U.S. Regulation," 138.

8. Since 1959 , of course, the public-interest theory on which Coase relied has fallen into disrepute, with the study of policy formation focusing increasingly on 
economic explanations, in which lawmakers are assumed to behave as simple rentseekers rather than as guardians of the public interest. This change was first evident in the works of Stigler, Posner, and Pelzman with respect to regulation; but it subsequently reached the study of legislation as well. See George J. Stigler, "The Theory of Economic Regulation," Bell Journal of Economics and Management Science 2 (1971): 3-21; Richard A. Posner, "Theories of Economic Regulation," Bell Journal of Economics and Management Science 5 (1974): 335-58; Sam Pelzman, "Toward a More General Theory of Regulation," Journal of Law $\mathcal{F}$ Economics 19 (1976): 211-40; George L. Priest, "The Origins of Utility Regulation and the "Theories of Regulation' Debate," Journal of Law EB Economics 36 (1993): 289-23.

9. With regard to the equal-time rule, for example, a Senate report stated explicitly in 1959, the year Coase published his article: "If the number of radio and television stations were not limited by available frequencies, the committee would have no hesitation in removing completely the present provision regarding equal time and urge the right of each broadcaster to follow his own conscience. . . However, broadcast frequencies are limited and, therefore, they have been necessarily considered a public trust" (Senate Report No. 562, 86th Cong., 1st sess. 1959, 8-9, as cited in Red Lion Broadcasting Co. v. FCC, 395 U.S. 367 [1969], 400).

10. Coase, "Federal Communications Commission," 25.

11. National Broadcasting Co. v. United States, 319 U.S. 190 (1943), 213, as quoted in Coase, "Federal Communications Commission," 12-13.

12. Coase, "Federal Communications Commission," 14.

13. The phrase "mysterious technology" appears in Coase, "Federal Communications Commission," 40.

14. Coase, "Federal Communications Commission," 25-26.

15. For historical treatments of American radio regulation prior to Hazlett, see esp. Jora R. Minasian, "The Political Economy of Broadcasting in the 1920s," Journal of Law $\mathcal{B}$ Economics 12 (1969): 391-403; Erik Barnouw, A History of Broadcasting in the United States: A Tower in Babel, Vol. 1-to 1933 (New York, 1966); Philip T. Rosen, The Modern Stentors: Radio Broadcasters and the Federal Government, $1920-$ 1934 (Westport, Conn., 1980).

16. Hazlett, "Rationality of U.S. Regulation," 138 (where the first reference to "error theory" appears). A survey of "error theory" literature can be found at 142, notes 25-27. See also Hazlett, "Assigning Property Rights to Radio Spectrum Users."

17. Ibid., 151.

18. Ibid., 152.

19. Herbert C. Hoover, "The Urgent Need for Radio Legislation," Radio Broadcast 2 (1923): 211, as quoted in Hazlett, "Rationality of U.S. Regulation," 152.

20. How important the Oak Leaves decision was in prompting federal action is a matter of some debate. Charlotte Twight, in particular, has argued that the ruling could not have been a pivotal factor since Congress had already begun moving toward enactment months before it was issued. See Charlotte Twight, "What Congressmen Knew and When They Knew It: Further Evidence on the Origins of U.S. Broadcasting Regulation," Public Choice 95 (1998): 247-76. Rather more sympathetic to Hazlett's account, Hugh Aitken concedes that it "is a heavy burden to place on a single decision in a single state court. Oak Leaves, however, was no ordinary decision. It was widely noted and widely discussed. It had the potential, if accepted as a precedent, to determine the future of the broadcasting industry" (Hugh G. J. Aitken, "Allocating the Spectrum: The Origins of Radio Regulation," Technology and Culture 35 [1994]: 712).

21. Hoover v. Intercity Radio Co., 286 Fed. 1003 (1923); United States v. Zenith Radio Corp., 12 F. 2d 614 (1926).

22. Hazlett, "Rationality of U.S. Regulation," 158.

23. Ibid., 158; Rosen, Modern Stentors, 93-95. 
24. Radio Act of 1927, P.L. 632, 44 Stat. Chap. 169, 23 February 1927, section $11,1167$.

25. Hazlett, "Rationality of U.S. Regulation," esp. 160-61.

26. Ibid., 175 .

27. Hazlett, "Assigning Property Rights to Radio Spectrum Users," 541.

28. Hazlett, "Rationality of U.S. Regulation," 162.

29. As quoted in Hazlett, "Assigning Property Rights to Radio Spectrum Users," 542.

30. Hazlett, "Rationality of U.S. Regulation," 172.

31. See esp. Hazlett, "Assigning Property Rights to Radio Spectrum Users."

32. Significantly, no other nation opted for a market-based solution. For a comparative international perspective on radio regulation, see Aitken, "Allocating the Spectrum," 688-89; Morton Keller, Regulating a New Economy: Public Policy and Economic Change in America, 1900-1933 (Cambridge, Mass., 1990), 82.

33. House of Representatives, Committee on the Merchant Marine and Fisheries, Hearings on H.R. 7357 To Regulate Radio Communication, 11-14 March 1924, 8,10 . The first sentence of this passage has been modified to correspond to the version, presumably corrected, that appears in the Congressional Record. See Congressional Record, 69th Cong., 2d sess., 1927, 68, pt. 3:2571.

34. House, Hearings, To Regulate Radio Communication, 36.

35. Ibid., 201, 202.

36. Ibid., 202.

37. Ibid., 202.

38. Hazlett, "Rationality of U.S. Regulation," 144.

39. See esp. House of Representatives, Committee on the Merchant Marine and Fisheries, Hearings, To Regulate Radio Communication, 6, 7, 14, 15 January 1926, 207-8.

40. Senate, Committee on Interstate Commerce, Hearings on S.1 and S.1754 Radio Control, Part I, 8-9 January 1926, 34.

41. Ibid., 39.

42. Ibid., 43-44.

43. Ibid., 42-44.

44. Ibid., 46.

45. Ibid., 47.

46. Congressional Record, 69th Cong., 2d sess., 1927, 68, pt. 3:2572. Ewin L. Davis was the ranking Democratic member of the radio subcommittee.

47. Congressional Record, 69th Cong., 1st sess., 1926, 67, pt. 5:5558. Johnson himself ultimately opposed the House bill because he did not think it went far enough in preventing monopoly.

48. Coase, "Federal Communications Commission," esp. 7, 12, and 38.

49. Clarence C. Dill, Radio Law: Practice and Procedure, (Washington, D.C., 1938), 82.

50. Radio Act of 1927, sections 13 and 17. The Radio Act is reprinted in Dill, Radio Law, 255-71. As former FCC chief economist Dallas Smythe explained, "Congress was impressed with the dangers of monopoly control over broadcasting by means of patents or any of the other devices which the fertile human mind might concoct, and wrote special sanctions into its broadcast policy. Ordinary private enterprise was subject to the Anti-trust laws. Additional penalties were prescribed for broadcasters who violated those laws" (Dallas W. Smythe, "A National Policy on Television?" Public Opinion Quarterly 14 [1950]: 465).

51. Legislators of the time frequently worried about industrial monopolies, and kept a particularly close eye on AT\&T. According to Ithiel de Sola Pool, the "frequent alarms [in the mid-1920s] about the threat of broadcasting monopoly" often had more to do with the specter of AT\& T than with the nascent broadcasting networks. See Ithiel de Sola Pool, Technologies of Freedom (Cambridge, Mass., 1983), 136. 
52. See Donald G. Godfrey and Val E. Limburg, "The Rogue Elephant of Radio Legislation: Senator William E. Borah," Journalism Quarterly 67 (1990): 214; Marvin Bensman, The Beginning of Broadcast Regulation in the Twentieth Century (Jefferson, N.C., 2000), 189.

53. Coase, "Federal Communications Commission," 16.

54. Carl J. Friedrich and Evelyn Sternberg, "Congress and Control of RadioBroadcasting I," American Political Science Review 37 (1943): 809.

55. Ibid.

56. Report cited in National Broadcasting Co. v. United States, 223.

57. Ibid., 224. See also discussion in section IV infra.

58. Radio Act of 1927, section 12.

59. Reaffirming the use of the ether for radio communication, or otherwise, to be the inalienable possession of the people of the United States and their government, House Report No. 719, 68th Cong., 1st sess., 13 May 1924, 3.

60. Coase, "Federal Communications Commission," 19.

61. Ibid., 14.

62. National Broadcasting Co. v. United States, 217.

63. Ibid., 217-18. 137.

64. Ibid., 219, citing FCC v. Pottsville Broadcasting Co., 309 U.S. 134 (1940),

65. FCC v. Pottsville Broadcasting Co., 138.

66. Coase, "Federal Communications Commission," 7.

67. National Broadcasting Co. v. United States, 227.

68. Red Lion Broadcasting Co. v. FCC, 387.

69. Ibid., 388-90. On Red Lion and the structure of radio regulation, see Edwin C. Baker, "Turner Broadcasting: Content-Based Regulation of Persons and Presses," in Dennis J. Hutchinson, David A. Strauss, and Geoffrey R. Stone, eds., The Supreme Court Review 1994 (Chicago, 1995), 57-128.

70. Hazlett, "Assigning Property Rights to Radio Spectrum Users," 568. $77-84$.

71. Clinton Rossiter, ed., The Federalist Papers, "No. 10," (New York, 1961),

72. The Federal Radio Commission, for example, declared in 1928, "There is not room in the broadcast band for every school of thought, religious, political, social, and economic, each to have its separate broadcasting station, its mouthpiece in the ether. If franchises are extended to some, it gives them an unfair advantage over others.... As a general rule, postulated on the laws of nature as well as on the standard of public interest, convenience, or necessity, particular doctrines, creeds, and beliefs must find their way into the market of ideas by the existing public service stations, and if they are of sufficient importance to the listening public the microphone will undoubtedly be available. If it is not, a well-founded complaint will receive the careful consideration of the Commission in its future action" (Great Lakes Broadcasting Company, unpublished 1928 report of the Federal Radio Commission, as quoted in "The Federal Radio Commission and the Public Service Responsibility of Broadcast Licensees," Federal Communications Bar Journal 11 [1950]: 8).

73. This story comes from the institutional economist John R. Commons, who claimed that it played an important role in inspiring his distinctive approach to economics. "Ever after," Commons wrote in his autobiography, "I looked for the omitted factors, or the ones taken for granted and therefore omitted, by the great leaders of the science of economics. That was how I became an economic skeptic" (John R. Commons, Myself [New York, 1934], 28).

74. Importantly, several particulars of the history of radio regulation cannot be explained by our fear-of-monopoly logic and instead are more consistent with Hazlett's franchise-rents framework. For instance, the failure to increase the spectrum available to broadcasters, in accordance with the wishes of big radio corpora- 
tions, suggests that more than anxiety over concentrated control of radio was at play. In addition, all users of radio waves, and not solely broadcasters, were subjected to extensive regulation. If only fear of political monopoly were at work, then nonbroadcast uses of the spectrum could have been left to the private market. Yet it appears from recent history that broadcasting is still regarded as special and that the fear of monopoly is still operative when it comes to the federal government's treatment of the spectrum. In the 1990s, Congress enthusiastically backed the auctioning of portions of the nonbroadcast spectrum but placed severe limits on the auctioning of broadcast licenses (Hazlett, "Assigning Property Rights to Radio Spectrum Users," 560-70; Aitken, "Allocating the Spectrum," 716; Keller, Regulating a New Economy, 81-85). As Hazlett himself acknowledged, "The broadcasting sector was pointedly singled out for special treatment" and "broadcasting license auctions have been authorized such that they will not much matter" (Hazlett, "Assigning Property Rights to Radio Spectrum Users,” 565, 568).

75. On criticism of the FCC, see, e.g., Hazlett, "Assigning Property Rights to Radio Spectrum Users," 540-41, 544. On the preference for commercial broadcasters, see Robert Horwitz, The Irony of Regulatory Reform: The Deregulation of American Telecommunications (New York, 1988), 167-74; Robert McChesney, Telecommunications, Mass Media, and Democracy: The Battle for the Control of U.S. Broadcasting, 1928-1935 (New York, 1993), chap. 2; Rosen, Modern Stentors, 12-13; Nathan Godfried, WCFL, Chicago's Voice of Labor, 1926-78 (Urbana, 1997).

76. See also Joseph P. Kalt and Mark A. Zupan, "Capture and Ideology in the Economic Theory of Politics," American Economic Review 74 (1984): 279-300.

77. Statement of Reed E. Hundt, Chairman, Federal Communications Commission, on Spectrum Management Policy, before the Subcommittee on Telecommunications, Trade, and Consumer Protection, Committee on Commerce, U.S. House of Representatives, Federal Document Clearing House Congressional Testimony, 12 February 1997. See also Gregory L. Rosston and Jeffrey S. Steinberg, "Using Market-Based Spectrum Policy to Promote the Public Interest," Federal Communications Commission Report, January 1997. Available at http://wireless.fcc.gov/ auctions/data/papersAndStudies.html.

78. Gregory L. Rosston and Thomas W. Hazlett et al., "Comments of 37 Concerned Economists," in the Matter of Promoting Efficient Use of Spectrum Through Eliminating Barriers to the Development of Secondary Markets, Federal Communications Commission, WT Docket No. 00-230, 7 February 2001, 2, 4, 7.

79. As quoted in Nicholas Lemann, "The Chairman: He's the Other Powell, and No One Is Sure What He's Up To," New Yorker, 7 October 2002, 48.

80. Ernest F. Hollings and Byron Dorgan, "Your Local Station, Signing Off," Washington Post, 20 June 2001, A27.

81. See, e.g., Yochai Benkler and Lawrence Lessig, "Net Gains," The New Republic, 14 December 1998, 12; Yochai Benkler, "Overcoming Agoraphobia: Building the Commons of the Digitally Networked Environment," Harvard Journal of Law $\mathcal{E}$ Technology 11 (1998): 287; Eli Noam, "Spectrum Auctions: Yesterday's Heresy, Today's Orthodoxy, Tomorrow's Anachronism. Taking the Next Step to Open Spectrum Access," Journal of Law $\mathcal{B}$ Economics 41(1998): 765; Lawrence Lessig, Code and Other Laws of Cyberspace (New York, 1999), 182-85; Cass R. Sunstein, "Television and the Public Interest," California Law Review 88 (2000): 511-12; Neil Hickey, "Power Shift: As the FCC Prepares to Alter the Media Map, Battle Lines Are Drawn," Columbia Journalism Review 41 (March-April 2003): 26-31.

82. Hollings and Dorgan, "Your Local Station, Signing Off." 